\title{
Sosialisasi, Literasi dan Implementasi Produk Perbankan Syariah
}

\author{
Mohammad Rizal $^{1}$, Arini Fitria Mustapita ${ }^{2}$, Arista Fauzi Kartika Sari ${ }^{3}$, \\ Dewi Diah Fakhriyyah ${ }^{4}$, Ahsani Taqwiem ${ }^{5}$ \\ 1,2Program Studi Manajemen, Universitas Islam Malang \\ 3,4Program Studi Akuntansi, Universitas Islam Malang \\ 5Program Studi Perbankan Syariah, Universitas Islam Malang \\ Email: ${ }^{1}$ mohammadrizal@unisma.ac.id, ${ }^{2}$ Arinimustapita@unisma.ac.id, \\ ${ }^{3}$ Aristakartika@unisma.ac.id, ${ }^{4}$ dewi_df@unisma.ac.id, \\ 5ahsani.taqwim@unisma.ac.id
}

\begin{abstract}
ABSTRAK
Iklim perbankan pada masa ini mulai berkembang semakin pesat, bisnis perbankan yang kompetitif dan ketat akan semakin tajam karena bermunculan bank-bank baru. Kegiatan pengabdian ini diharapkan dapat memberi bekal kepada peserta, sehingga dapat meningkatkan perekonomian syariah. Pemahaman produk perbankan syariah akan memberikan manfaat bagi mereka dalam hal perekonomian syariah. Adapun alur metode pengabdian pada masyarakat dengan menggunakan tahapan Sosialisasi, Literasi dan Implementasi dengan subjek dampingan yang menjadi mitra kegiatan pengabdian masyarakat ini adalah Karang Taruna dan Warga Dinoyo di Kecamatan Lowokwaru Kota Malang. kegiatan pengabdian kepada masyarakat ini terdiri 3 tahapan, yaitu identifikasi masalah, pelaksanaan kegiatan, dan evaluasi pelaksanaan. Hasil pelaksanaan kegiatan ini adalah Peserta menyatakan rasa terima kasih kepada kami karena telah diberikan kesempatan untuk mengikuti kegiatan literasi dan sosialisasi perbankan syariah sehingga dapat membuka pikiran mereka yang selama ini merasa bank konvensional dan bank syariah sama saja. Hal ini menunjukkan bahwa literasi dan sosialisasi perbankan syariah di masyarakat masih kurang gencar sehingga kegiatan-kegiatan seperti ini seharusnya lebih sering dilakukan.
\end{abstract}

Kata Kunci: Perbankan Syariah, Sosialisasi, Literasi, Implementasi

\section{ABSTRACT}

The banking climate at this time is starting to develop more rapidly, the competitive and tight banking business will be sharper due to the emergence of new banks. This service activity is expected to provide provisions for participants, so that they can improve the sharia economy. Understanding of Islamic banking products will provide benefits for them in terms of the Islamic economy. The flow of the method of community service using the stages of Socialization, Literacy and Implementation with the assisted subjects who are partners in this community service activity are Karang Taruna and Dinoyo Residents in Lowokwaru District, Malang City. This community service activity consists of 3 stages, namely problem identification, activity implementation, and implementation evaluation. The result of this activity is that Participants express their gratitude to us for being given the opportunity to participate in Islamic banking literacy and socialization activities so that they can open their minds who have always felt that conventional banks and Islamic banks are the same. This shows that the literacy and socialization of Islamic banking in the community is still not intensive enough so that activities like this should be carried out more often.

Keywords: Islamic banking, socialization, literacy, implementation 


\section{PENDAHULUAN}

Perbankan

berkembang seiring berjalannya waktu, terutama ketika disahkannya dasar hukum operasional tentang perbankan melalui UU No 7 Tahun 1992, dan kemudian dirubah dalam Undang-Undang No 10 Tahun 1998. Undang-undang tersebut memberikan kesempatan yang lebih luas untuk bank syariah dan sebagai penguatan dari Bank Indonesia sebagai stake holder dalam bidang moneter bank syariah (Utami, 2017).

Pada Undang-Undang No. 21 Tahun 2008 tentang Perbankan Syariah Pasal 1 menyatakan bahwa Perbankan Syariah ialah semua hal yang membahas mengenai bank syariah ataupun unit usaha syariah, baik mengenai kelembagaan, kegiatan usaha (dalam bidang moneter), dan juga sistematika dalam menjalankan kegiatan usahanya. Bank syariah difokuskan sebagai kekuatan bisnis keuangan yang menjalankan kegiatan usahanya mengikuti dasar ekonomi Islam. Dalam bank syariah arah tujuan tidak hanya diutamakan pada profit semata yang terlihat mengenai percapaian maximal profit, akan tetapi tugasnya adalah mencapai kesejahteraan secara luas untuk seluruh masyarakat. Bank syariah dalam pelaksanaan fungsi sosialnya salah satunya adalah memberikan kontribusi untuk turut serta dalam mewujudkan kesejahteraan masyarakat tersebut (Susono, 2019).

Iklim perbankan pada masa ini mulai berkembang semakin pesat, bisnis perbankan yang kompetitif dan ketat akan semakin tajam karena bermunculan bankbank baru. Fakta seperti ini harus dilandasi dengan persiapan dan kekuatan yang baik dari bank-bank tersebut agar setiap bank dipaksa untuk mempersiapkan pendekatan dalam memperkuat usahanyanya (Supriyanti, 2019).

Tabel 1 Perkembangan Jumlah Bank Syariah di Indonesia

\begin{tabular}{|c|c|c|c|c|c|c|}
\hline \multirow[t]{2}{*}{ No } & \multirow[t]{2}{*}{ Keterangan } & \multicolumn{5}{|c|}{ Jumlah Bank } \\
\hline & & 2017 & 2018 & 2019 & 2020 & 2021 \\
\hline 1. & $\begin{array}{l}\text { Bank Umum } \\
\text { Syariah }\end{array}$ & 13 & 14 & 14 & 14 & 14 \\
\hline 2. & $\begin{array}{l}\text { Unit Usaha } \\
\text { Syariah }\end{array}$ & 344 & 354 & 375 & 392 & 351 \\
\hline 3. & $\begin{array}{l}\text { Bank } \\
\text { Pembiayaan } \\
\text { Rakyat } \\
\text { Syariah }\end{array}$ & 167 & 167 & 164 & 163 & 163 \\
\hline
\end{tabular}

tahun 2017 hingga tahun 2021 terdapat bank umum syariah, unit usaha syariah dan bank pembiayaan rakyat syariah mengalami perkembangan dan penurunan jumlah. Apabila melihat dari sudut pandang nasional, bank-bank syariah yang berhadapan secara langsung dengan bankbank konvensional memang berkembang cukup pesat. Jika melihat sudut pandang internasional, pada Islamic Finance Country Index (GIFR, 2017) terlihat Indonesia menduduki peringkat ke-7 sesudah Malaysia, Iran, Saudi Arabia, United Arab Emirates, dan Kuwait. Namun ketika tahun 2016 Indonesia menduduki peringkat ke-6, dapat diartikan minus satu peringkat. Pada bisnis keuangan syariah dapat dikatakan bergerak disatu tempat saja apabila disandingkan dengan negara-negara tersebut. Disisilain, angka diatas menjelaskan bahwa negara kita adalah negara yang potensial untuk tumbuhnya bisnis perbankan syariah di masa depan, yg perlu diingat Indonesia mempunyai jumlah penduduk muslim terbesar. 
Hingga sekarang sosialiasi pada bank-bank syariah belum efisien dan efektif dikarenakan sosialisasi terlalu fokus pada Islamisasi, yaitu hanya fokus pada prinsipprinsip Islam yang diimplementasikan pada sistem perbankan, sosialisasi yang dilaksanakan belum mencapai tahap saintifikasi sehingga sosialisasi bank-bank syariah menjadi kurang efektif. Kurang efisien dan efektifnya sosialisasi itu dikarenakan minimnya usaha untuk melakukan sosialisasi unsur-unsur Islam supaya diterima oleh masyarakat secara luas dan rasional, agar bank-bank syariah tidak hanya dipercaya keunggulannya di kalangan fanatisme syariah tetapi juga dapat lebih ke semua kalangan. Dalam data dijelaskan bahwa market share dari perbankan syariah tidak lebih dari $5 \%$ dari total market perbankan secara umum (Erfanto, 2016).

Bertahannya market share perbankan syariah sejak belasan tahun diatas satu koma, karena kegiatan sosialisasi yang dilakukan masih minim (belum maksimal) dan belum tepat sasaran. Dengan pertumbuhan efisien dan efektivitas sosialisasi perbankan syariah diharapkan mempunyai daya saing yang tinggi di dalam negeri sebagai pondasi untuk tetap berdiri dan melawan persaingan di era MEA, mengingat sebagai negara dengan penduduk muslim terbesar, sudah selayaknya Indonesia menjadi pelopor dan kiblat pengembangan keuangan syariah (Santoso, 2019). Padahal masyarakat sangat menginginkan banyak informasi mengenai perbankan syariah.

Optimalisasi untuk efesien dan efektivitas sosialisasi bank-bank syariah harus ditingkatkan, maka dilakukanlah usaha yang lebih realistis. Demi sebuah tujuan yang diharapkan untuk memperbaiki dalam hal mensosialisasikan bank-bank syariah di tengah masyarakat, hal itu dapat dinilai dari faktor-faktor fundamental dalam meningkatkan efesien dan efektivitas sosialisasi bank-bank syariah di tengah masyarakat. Tidak sedikit orang yang berfikir bahwa menyimpan uang pada bank syariah sama saja dengan dengan menyimpan uang pada bank konvensional (Kusnandar, 2018). Hal tersebut dapat dinilai dari lemahnya perkembangan bank-bank syariah, padahal bank-bank syariah mempunyai potensi yang besar.

Peningkatan bank-bank syariah yang belum signifikan dikarenakan karena program dari sosialisasi yang dilakukan belum maksimal. Pola pikir masyarakat yang masih belum merata yang menyebabkan hal tersebut terjadi, apabila dibandingkan dengan bank konvesional, masyarakat belum begitu mengenal dan mengenai bank syariah, dan ada banyak masyarakat ragu-ragu dengan penerapan konsep riba pada bunga bank (Satiti, 2020).

The Asian Banker pada tahun 2021 menjelaskan Timur Tengah masih mendominasi daftar bank syariah terbesar di dunia pada 2020. Selain Jazirah Arab, Malaysia dan Indonesia juga jadi negara yang dominan menyumbang daftar, masingmasing dengan 16 dan 14 bank syariah. Namun secara peringkat, bank syariah Malaysia jauh lebih unggul dari milik Indonesia. Tercatat sebanyak 9 di antaranya berada di posisi lebih tinggi dari Bank Syariah Mandiri, yang jadi bank syariah asal Indonesia dengan peringkat tertinggi di posisi 34. Negeri Jiran pun menyumbang dua perusahaan dalam daftar 10 bank syariah terbesar dunia. (liputan.6.com). 
Dapat diartikan, sosialisasi perbankan syariah masih belum merata dalam masyarakat. Masyarakat berbagai segmentasi belum banyak memahami produk, sistem, konsep, filosofi, keuntungan dan kekuatan pada bank syariah. Paling tidak ada 2 masalah dalam perbankan syariah dan diasumsikan salah oleh masyarakat. Pertama, mengenai bagi hasil dan pembiayaan dengan suku bunga (interest rate) yang menjadi umum di Indonesia misalnya BI rate atau LIBOR di level internasional (Supriyanto, 2015). Masalah Kedua adalah pembiayaan pada bank syariah yang diasumsikan hanya menganut prinsip bagi hasil (Amar dan Setiawan, 2017).

Perbankan syariah memiliki arti yang luar biasa bagi pertumbuhan ekonomi syariah dan yang terpenting dalam memberikan jalan keluar bagi pemberdayaan usaha kecil dan menengah dan juga menjadi kekuatan utama ekonomi kerakyatan dan menjadi pondasi sistem perekonomian nasional. Peranan bank Syariah menjadi suatu lembaga intermediasi yang mampu mengatasi permasalahan fundamental yang dihadapi oleh pengusaha kecil dan menengah khususnya di bidang keuangan dan permodalan berbasis syariah.

Kegiatan pengabdian ini diharapkan dapat memberi bekal kepada Karang Taruna dan Warga Dinoyo di Kecamatan Lowokwaru Kota Malang, sehingga dapat meningkatkan perekonomian syariah bagi konsumen/nasabah ataupun perbankan. Pemahaman Produk Perbankan Syariah akan menyalurkan manfaat dalam hal perekonomian syariah. Pemahaman terhadap Produk Perbankan Syariah tentunya akan menolong Karang Taruna dan Warga Dinoyo di Kecamatan Lowokwaru Kota Malang untuk melakukan pembukuan yang baik dalam sumber dana dan penggunaan secara Syariah, cermat dan efisien sehingga Warga Dinoyo di Kecamatan Lowokwaru Kota Malang bisa berkembang lebih baik dalam perekonomian khususnya perekonomian syariah.

\section{METODE PENELITIAN}

Sasaran yang didapatkan adalah Warga Dinoyo di Kecamatan Lowokwaru Kota Malang sejumlah 25 orang. Pemilihan responnden ini adalah suatu usaha untuk menumbuhkan pemahaman produk perbankan syariah yang berkembang. Lebih jauh dari itu, harapannya peserta pelatihan dapat menularkan ilmu yang didapatkan kepada warga lain yang berada di sekitarnya.

Adapun alur metode pengabdian pada masyarakat dengan menggunakan tahapan sebagai berikut: Pelaksanaan Pengabdian Pada Masyarakat ini dilaksanakan dengan cara penyuluhan, demonstrasi, pelatihan, bimbingan, diskusi, konsultasi dan evaluasi program. Adapun prosedural dalam kegiatan pengabdian ini adalah:

1. Sosialisasi dan Literasi: Sosialisasi dan Literasi merupakan cara tepat dalam menyampaikan ilmu pengetahuan kepada masyarakat untuk mengoptimalkan kegiatan dan hasil Sosialisasi dan Literasi. Brosur, form atau leaflet mengenai produk bank syariah diberikan pada semuan peserta sosialisasi dan literasi.

2. Implementasi: selain pemberian modul tentang akad serta produk-produk syariah, dalam pelatihan ini 
memperkenalkan serta memberi contoh implementasi perhitungan untuk hasil yang diantaranya tata cara perhitungan untuk hasil, tahapan perhitungan untuk hasil, aspek penentu untuk hasil dan contoh permasalahan perhitungan untuk hasil serta profit margin perbankan Syariah

3. Diskusi dan Konsultasi: Pada dikala sosialisasi serta literasi diiringi dengan dialog serta konsultasi buat lebih menguatkan aktivitas dedikasi kepada warga yang dilaksanakan.

4. Evaluasi Program: Penilaian akhir aktivitas dicoba buat mengukur pencapaian dari segala program pelatihan. Ada pula penanda keberhasilan dari aktivitas ini diresmikan terdapatnya pengingkatan yang signifikan dari pra pelatihan sampai pasca pelatihan serta pula dalam aktivitas pelatihan ini partisipan bisa menguasai konsep serta sistem dari perbankan Syariah.

Secara teknis, kegiatan pengabdian kepada masyarakat ini terdiri 3 tahapan sebagaimana tercantum pada foto tahapan aktivitas dedikasi berikut ini:

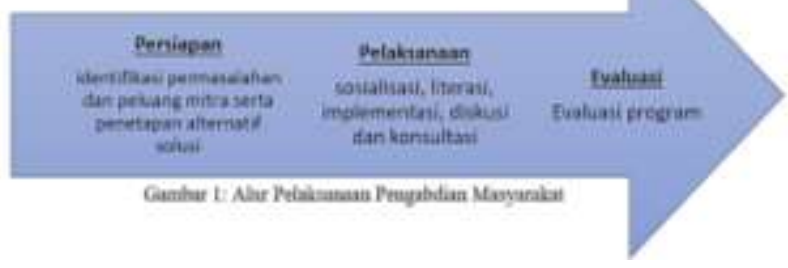

Tingkat keberhasilan dalam pelaksanaan program dievaluasi memakai pre test dan post test serta lembar evaluasi oleh subjek dampingan, yaitu pada Karang Taruna dan Warga Dinoyo di Kecamatan Lowokwaru Kota Malang.

\section{HASIL DAN PEMBAHASAN}

Pelaksanaan pada kegiatan pengabdian masyarakat ini dilaksanakan dalam tiga tahapan sebagai berikut

1. Persiapan: Kegiatan yang ini dilaksanakan pada tanggal 20 Februari 2021 yang bertujuan untuk mengidentifikasi dan memilih fokus permasalahan. Identifikasi masalah dilakukan bersama dengan kepala Karang Taruna dan perwakilan warga Dinoyo di Kecamatan Lowokwaru Kota Malang. Hasil pelaksanaan pada tahap pertama ini adalah masih minimnya pemahaman Karang Taruna dan warga Dinoyo di Kecamatan Lowokwaru Kota Malang mengenai Produk Perbankan Syariah, hal ini dapat diketahui dari hasil pre test yang diberikan saat awal pertemuan kepada 25 orang dalam bentuk pertanyaan-pertanyaan mengenai perbankan syariah.

Pada gambar 2 diatas dapat dijelaskan bahwa tingkat pemahaman produk bank syariah di Karang Taruna dan Warga Dinoyo masih dapat dikatakan kurang, hal ini dikarenakan juga pada daerah tersebut belum pernah ada yang melakukan sosialisasi mengenai produk perbankan syariah.

2. Pelaksanaan: Kegiatan pengabdian yang dilakukan kepada warga Dinoyo di Kecamatan Lowokwaru, Malang telah berjalan mengikuti yang diharapkan, adapun beberapa tahapan yang dilakukan.

\section{- Sosialisasi dan Literasi Perbankan Syariah}

Sebelum penjelasan materi, tim pengabdi menyampaikan beberapa pertanyaan pembukan untuk mengetahui pemahaman awal dari peserta. Hasilnya adalah sebagian besar Karang Taruna dan masyarakat Dinoyo ternyata masih awam dengan perbankan syariah, dan mereka 
menganggap bahwa perbankan syariah dan konvensional itu sama saja, hanya penggantian penyebutan dnegan menggunakan bahasa arab. Meskipun beberapa di antara peserta telah memahami lembaga keuangan syariah, dan produk perbankan syariah.

Pemaparan materi sosialisasi dan literasi pada perbankan syariah ini mencakup pemaparan pengetahuan umum keuangan syariah, beda antara bank syariah dan bank konvensional, serta produkproduk bank syariah yang bisa digunakan oleh masyarakat Dinoyo. Pemaparan materi tersebut tentunya disampaikan dengan bahasa yang dapat dengan mudah diterima oleh masyarakat Dinoyo dan Untuk memudahkan penyampaian informasi, tim pengabdi membuat langkah-langkah dalam penyajian materi, dimulai pemberian materi dasar tentang ekonomi islam, secara garis besar hingga materi yang lebih tajam yang berkenaan dengan keuangan dan perbankan syariah. materi tersebut juga dipaparkan secara berkelanjutan. Hal ini dapat mengefisienkan waktu untuk melakukan pengabdian.

Pelatihan mengenai akad dan produk perbankan syariah mengenai materi dasar tentang filosofi transaksi di bank syariah dari sisi produk hingga manejemen operasional, dari sisi praktis, birokratis dan akademis. Tahapan materi yang diberikan s meliputi pengenalan transaksi terlarang seperti prinsip muammalah seperti riba, tadlis, taghrir dan persaingan tidak sempurna (bai' najasy dan ikhtikar) ada juga mengenai teori akad dan wa'ad, Designing Syariah Contract, Karakteristik Pasar, Produk Pembiayaan Bank Syariah, Teknik Perhitungan Dana Pihak Ketiga dan Pembiayaan.

\section{- Implementasi Perbankan syariah}

Setelah dilakukan proses sosialisasi dan literasi mengenai pengetahuan dasar di bank syariah, maka tim pengabdi menjelaskan hal-hal mengenai implementasi perkembangan perbankan syariah di dunia, dan khususnya di indonesia. Beberapa warga sangat mengapresiasi dengan adanya sosialiasi yang dilakukan oleh tim pengabdi. Hal itu dikarenakan masih kurangnya sosialisasi secara langsung yang dilakukan oleh pemerintah untuk masyarakat mengenai perbankan syariah, itulah yang membuat masyarakat berasumsi bahwa bank syariah dan bank konvensional sebenarnya sama saja, namun berbeda penyebutannya yang agak "kearab-araban".

Dalam proses implementasi perbankan syariah ini tim pengabdi memperagakan, memberikan contoh dan memberikan kasus cara implementasi tata cara bagi hasil yang mulai dari metode perhitungan bagi hasil, langkah perhitungan bagi hasil, faktor penentu bagi hasil hingga contoh kasus perhitungan bagi hasil dan profit margin perbankan Syariah.

Hasil dalam proses implementasi terbukti adanya pertumbuhan yang cukup berpengaruh tentang akad yang dipakai lembaga keuangan syariah dan memahami perbedaan bank syariah dan bank konvensional hal ini didapatkan pada sesi tanya jawab sederhana dari tim pengabdi kepada Karang Taruna dan warga Dinoyo sedangkan bagi masyarakat yang masih belum paham atau dirasa ada kelanjutan setelah adanya penjelasan materi yang dilakukan oleh tim pengabdi, tim pengabdi memberikan waktu dan kontak person untuk dapat dihubungi oleh peserta. Bahkan itu yang tim pengabdi harapkan, setelah 
adanya sosialisasi ini, dapat meningkatkan kesadaran masyarakat dinoyo untuk melakukan transaksi, minimal menabung di bank syariah. Jika melihat keadaan ini tentunya dapat membantu stake holder untuk menimbuhkan kontribusi masyarakat kepada ekonomi syariah. Jadi ketika Indonesia mendapat bonus demografi pada tahun 2030, industri keuangan Syariah akan mendapatkan peranan penting sepenuhnya dan dampaknya akan didapatkan oleh masyarakat Indonesia.

\section{- Diskusi dan Konsultasi}

Pada sesi terakhir kegiatan ini kami membuka kesempatan konsultasi bagi peserta yang telah mengikuti dari sesi sebelumnya. Beberapa peserta antusias untuk bertanya, berikut adalah beberapa rekapan pertanyaan dari peserta:

Pertanyaan dari Bapak Robi, Beliau sedang mencari rumah dan sedang survey untuk pengajuan KPR. Menurut beliau cicilan dengan menggunakan bank syariah lebih tinggi daripada menggunakan bank konvensional, apakah penyebab dari hal tersebut? Cicilan pembiayaan rumah di bank syariah biasanya menggunakan akad murabahah yang mekanismenya adalah nasabah mengajukan permohonan pembiayaan rumah kemudian bank membelikan rumah tersebut dan menjualnya kepada nasabah dengan marjin keuntungan yang telah didiskusikan oleh pihak bank dan nasabah. Setelah terjadi kesepakatan, nasabah mencicil pembelian rumah tersebut sesuai jangka waktu yang telah ditetapkan dan nilai cicilan yang tidak akan berubah hingga cicilan lunas. Walaupun seperti itu, bila dihitung dengan total cicilan dengan bunga, dengan KPR syariah maupun konvensional akan sama ketika tenor berakhir. Hanya, cicilan KPR syariah tampak besar ketika awal jika disandingkan bank konvensional. Bank konvensional melakukan penyesuaian berupa floating rate yang bahkan ratenya bisa naik hingga $100 \%$.

Pertanyaan dari Mas Anton, Jika kita ingin meminjam uang (pembiayaan) di bank syariah apakah kita bisa menawar bagi hasil yang ditetapkan? Pembiayaan berbasis bagi hasil bagi di bank syariah menggunakan akad mudharabah dan musyarakah. Keduanya tidak diperkenakan adanya beban dana yang bersifat tetap. Besarnya bagi hasil ditentukan oleh nisbah yang disepakati oleh bank dan nasabah baik menggunakan revenue sharing atau pun profit sharing. Besaran nisbah harus berbentuk porsi perbandingan seperti 40 : 60 . Tidak diperbolehkan menentukan bagi hasil dengan persentase yang tetap seperti halnya suku bunga. Setiap bank syariah memiliki acuan hitungan nisbah tersendiri didasarkan kepada kondisi keuangan, tingkat risiko, kapasitas, target bisnis dan strategi yang dipilih. Negosiasi nisbah dimungkinkan biasanya pada transaksi pembiayaan yang besarannya signifikan.

Pertanyaan dari Mbak Mega Ayu Menurut saya bunga dan bagi hasil itu sama saja, sama-sama mendapatkan keuntungan atau "imbalan" hanya menggunakan istilah yang berbeda saja. Sistem bunga pada bank konvensional menggunakan prosentase yang mana besarannya telah ditentukan pihak bank yang seringkali bank tidak menginformasikan berapa persen bunganya, sedangkan pada bagi hasil menggunakan perbandingan misalkan 40:60 yang telah diinformasikan di awal kepada nasabah. Nantinya perbandingan tersebut menjadi dasar perhitungan bagi hasil yang akan 
diperoleh oleh nasabah tergantung dari besaran simpanan dan besaran dana yang dikelola oleh bank. Pada bunga hanya menggunakan asumsi selalu untung (pada pembiayaan) sehingga peminjam dana diharuskan membayar cicilan walaupun usahanya mengalami kerugian, sedangkan pada bagi hasil masih mengenal asumsi rugi, jadi ketika mengalami kerugian maka kerugian ditanggung bersama (tergantung akad mudharabah apa yang digunakan). Selain itu bunga dihitung dari besaran pinjaman atau kredit sedangkan bagi hasil dari besaran keuntungan dari kegiatan yang dibiayai sehingga nilai berfluktuasi.

\section{Evaluasi Program}

Kegiatan Sosialisasi, Literasi dan Implementasi Produk Perbankan Syariah telah dilaksanakan selama empat hari dan berjalan dengan lancar, segala proses telah dilalui dengan baik. Kami para pengabdi telah melakukan persiapan sebaik mungkin demi kelancaran proses sehingga kegiatan ini tidak mengalami hambatan yang berarti. Namun, yang menjadi perhatian bagi kami adalah mayoritas peserta menanyakan hal yang sifatnya spesifik pada suatu produk perbankan syariah tertentu sedangkan kami bukanlah pihak yang memahami secara mendalam suatu produk perbankan syariah tertentu. Hal ini dapat menjadi masukan bagi kami bahwa kami perlu setidaknya mengenal bahkan mungkin membandingkan setiap produk dari masingmasing perbankan syariah sehingga dapat memberikan informasi yang lebih spesifik kepada peserta. Beruntungnya kami menjadi nasabah di beberapa bank syariah sehingga ada gambaran sedikit perbandingan di antara beberapa bank syariah walaupun tidak secara keseluruhan, inilah yang menjadi bekal kami untuk memberikan gambaran yang lebih nyata untuk menjawab pertanyaan peserta dan selain itu hal ini juga diperkuat dari salah satu tim pengabdi yang pernah menjadi banker disalah satu bank.

Dalam program pengabdian ini juga ada hal yang dilakukan diluar rencana, salah satunya adalah memperkenalkan relasi dari tim pengabdi yaitu tim marketing dari bank muamalat yang sempat menambahkan materi-materi tambahan mengenai produk pada bank syariah serta menjelaskan prosedural mengenai KPR pada bank syariah hingga pembiayaan. Karang Taruna dan Warga Dinoyo juga terlibat erat dengan presentasi tersebut dan sebagian peserta ada yang membuka account bahkan ada yang mengajukan untuk pembiayaan. Setelah pendampingan dan penyampaian materi yang telah diberikan, peserta dipersilahkan untuk mengerjakan kuis agar tim pengabdi mengetahui pemahaman dari peserta mengenai materi yang telah disampaikan. Pertanyaan-pertanyaan yang disampaikan tentang materi yang disampaikan sebelumnya. Kegiatan tersebut, dilaksanakan menggunakan aplikasi https://kahoot.com Hasil dari pertanyaanpertanyaan menjadi indikator pemahaman bahan materi peserta dapat dilihat pada gambar 3 berikut ini

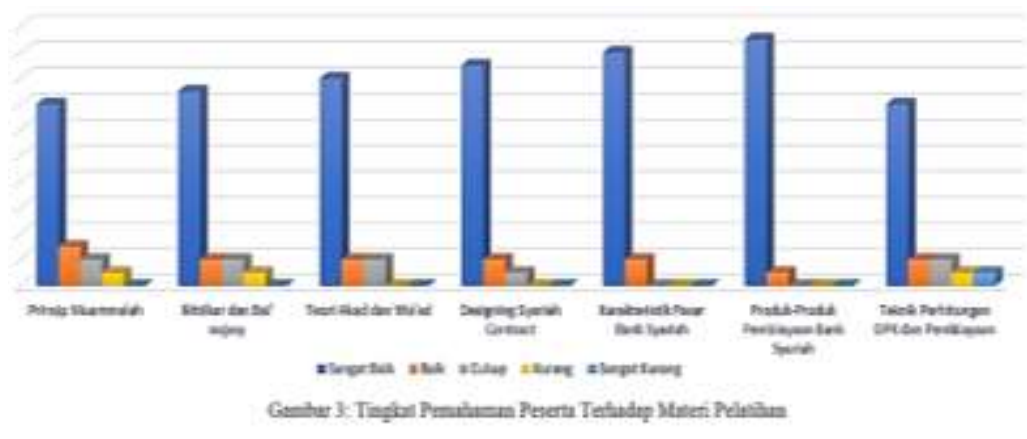

Pada tahap akhir sosialisasi 
dilaksanakan evaluasi dengan kuesioner secara online kepada peserta tentang bank syariah seperti pra pengabdian. Hasilnya dapat dilihat pada gambar 4 yang terlihat bahwa dengan dasar evaluasi para peserta, pada aspek pemahaman sudah mengalami peningkatan yang sangat signifikan dan relatif sangat baik, dengan persentase memahami ekonomi syariah yang menjadi $60 \%$, untuk mengenal produk bank syariah $85 \%$, mempunyai produk bank syariah 35\%, mempunyai relasi pada bank syariah $90 \%$, pernah mengajukan pembiayaan pada bank syariah $35 \%$ dan mempunyai keinginan pada produk bank syariah $75 \%$.

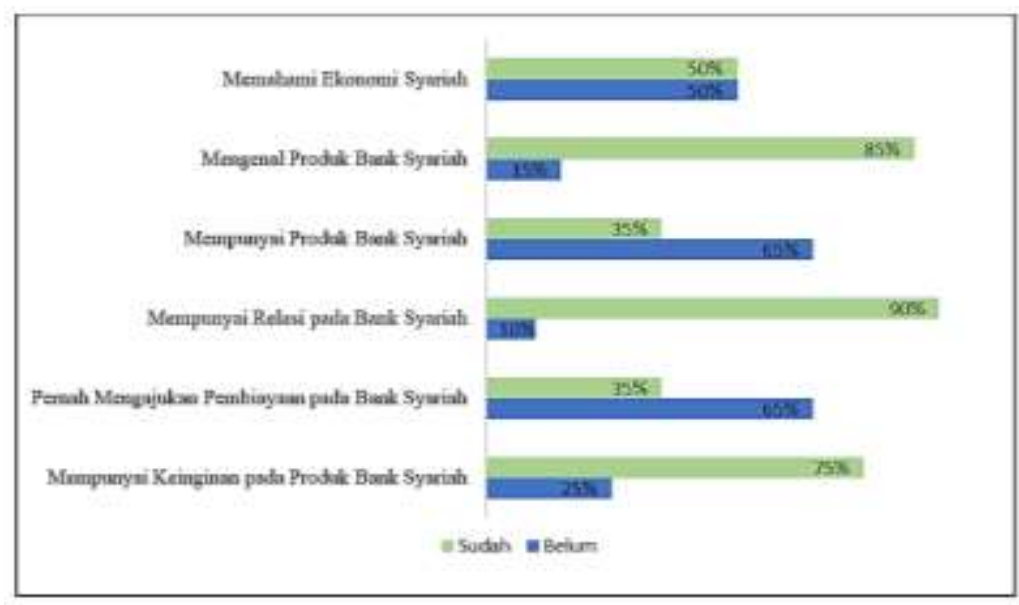

Gambar 4: Kondisi Setelah Sosialisasi Karnng Tamıa dan Warga Dinoyo

\section{SIMPULAN}

Kegiatan Sosialisasi, Literasi dan Implementasi Produk Perbankan Syariah yang dilakukan pada warga kelurahan Dinoyo kecamatan Lowokwaru Kota Malang telah dilaksanakan berjalan seperti diharapkan. Hal ini dapat dilihat dari peningkatan pengetahuan peserta mengenai perbankan syariah dari sebelum adanya kegiatan dan setelah adanya kegiatan, selain itu dapat dilihat dari respon positif dari para peserta dengan beberapa pertanyaan dan diskusi terkait perbankan syariah, bahkan secara terang-terangan peserta menyatakan akan segera menjadi nasabah bank syariah. Peserta menyatakan rasa terima kasih kepada kami karena telah diberikan kesempatan untuk mengikuti kegiatan literasi dan sosialisasi perbankan syariah sehingga dapat membuka pikiran mereka yang selama ini merasa bank konvensional dan bank syariah sama saja. Hal ini menunjukkan bahwa literasi dan sosialisasi perbankan syariah di masyarakat masih kurang gencar sehingga kegiatan-kegiatan seperti ini seharusnya lebih sering dilakukan. Tentunya hal ini dapat menjadi masukan juga bagi bank syariah agar lebih gencar memperkenalkan produk mereka ke masyarakat.

\section{DAFTAR PUSTAKA}

Amar, F., \& Setiawan, E. (2017). Determinan penggunaan rekening bank syariah pada pengelola masjid di DKI Jakarta. IKONOMIKA: Journal of Islamic Economics and Business, 2, 201-212.

Erfanto, L. (Ed). (2016). Market share perbankan syariah masih rendah. Retrieved November May 20, 2018 from https://ekbis.sindonews.com/read/1104 885/178/market-share- perbankansyariah-masih-rendah-1461855815 diakses pada 20 Februari 2021

Global Islamic Finance Report. (2017). Islamic Finance Country Index. (online). http://gifr.net/. Diunduh pada 15 September 2020.

Kusnandar, N. (2018). Persepsi masyarakat tentang bank syari'ah (Studi kasus di Kelurahan Jatijajar, Tapos, Depok Jawa Barat). Al Mashalih: Journal of Islamic Law, 1, 62-76.

Liputan 6. Daftar 10 Bank Syariah Terbesar Dunia https:// www.liputan6.com/bisnis/read 44472869/daftar-10-bank-syariahterbesar-dunia Diakses: 1 September 2021.

Otoritas Jasa Keuangan. Statistik Perbankan Syariah Januari (2021). https://www.ojk.go.id/id/kanal/perba nkan/data-dan-statistik/statistikperbankan-indonesia/default.aspx diakses pada 15 Februari 2021. 
Santoso, Ivan Rahmat (2019). Sosialisasi dan Pelatihan Implementasi Akad-Akad dan Produk Perbankan Syariah. Jurnal Pengabdian Pada Masyarakat, 2019, Vol. 3 No. 2, Page: 151-158. Universitas Mathla'ul Anwar Banten.

Satiti, Abidah Dwi Rahmi dkk. (2020). Sosialisasi Dan Pelatihan Implementasi Akad-Akad Dan Produk Perbankan Syariah Pada Koperasi Wanita Desa Tambakrigadung Kecamatan Tikung Kabupaten Lamongan. TRIDARMA: Pengabdian Kepada Masyarakat (PkM) Vol 3 No 1, Mei (2020).

Setia, Utami, (2017). Pengaruh Persepsi Masyarakat Tentang Perbankan Syariah Terhadap Minat Menabung di Bank Syariah (Studi Kasus Pada Masyarakat Muslim Kauman Wijirejo Pandak Bantul). Skripsi, Yogyakarta: UIN Sunan Kalijaga. Supriyanto, T. (2015). Konsep rate of profit dan stabilitas ekonomi perbankan syariah. Etikonomi, 14(2), 175-204.

Susono, Juhasdi. (2019). Periodisasi Perkembangan Hukum Perbankan Syariah di Kabupaten Bone. Jurnal AlDustur; Vol 2 NO 1, Juni 2019. Institut Agama Islam Negeri (IAIN) Bone.

Tufy, Supriyanti. (2019). Pengaruh Aksebilitas dan Persepsi Kualitas Pelayanan Terhadap Minat Menabung di Perbankan syariah (Studi pada Anggota Difabel Blora Mustika) Universitas Islam Negeri Sunan Kalijaga.

Undang Undang No 7 tahun 1992 tentang Perbankan sebagaimana telah diubah dengan Undang Undang No. 10 tahun 1998.

Undang-Undang Republik Indonesia Nomor 20 Tahun 2008 Tentang Usaha Mikro, Kecil, dan Menengah dan Undang-Undang Republik Indonesia Nomor 21 Tahun 2008 Tentang Perbankan Syari'ah. 